Cite this: RSC Adv., 2015, 5, 49987

Received 14th April 2015

Accepted 27th May 2015

DOI: $10.1039 / c 5 r a 06693 j$

www.rsc.org/advances

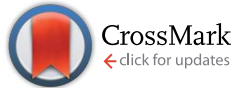

\section{Kinetic characterisation of the FAD dependent monooxygenase TropB and investigation of its biotransformation potential $\uparrow$}

\author{
Amira Abood, t $^{\mathrm{ab}}$ Ahmed Al-Fahad, t $^{\mathrm{ac}}$ Alan Scott, ${ }^{a}$ Alaa El-Dein M. S. Hosny, ${ }^{\mathrm{d}}$ \\ Amal M. Hashem, ${ }^{b}$ Azza M. A. Fattah, ${ }^{b}$ Paul R. Race, ${ }^{e}$ Thomas J. Simpson ${ }^{a}$ \\ and Russell J. Cox*af
}

Achieving regio-specific hydroxylation of aromatic compounds remains a major challenge in synthetic chemistry. By contrast, this transformation is readily accomplished in nature through the action of FADdependant monooxygenase enzymes. Here, we report the kinetic characterisation of one such enzyme, TropB, from the stipitatic acid biosynthetic pathway. Analogues of the TropB natural substrate, 3-methylorcinaldehyde, were synthesised and used to examine the substrate selectivity of this enzyme. TropB displays broad substrate tolerance, for instance accepting single-ring aromatic substrates containing a range of C-1 substituents with varying electronic and steric properties. These include nitro, nitrosyl, alkyl, and aryl keto groups. Bicyclic substrates, however, were rejected by TropB. Additionally, C- 5 substituents on single-ring aromatic substrates were not tolerated whereas the presence of a 6-methyl group was found to be important for substrate binding. Docking studies were employed to investigate and understand the broad substrate selectivity of TropB and identifies the key structural elements of its substrates. Our work has shown that TropB is an attractive target for biocatalyst engineering and industrial aromatic hydroxylation.

\section{Introduction}

The direct hydroxylation of aromatic compounds in a chemo-, regio- and stereo-selective manner remains a major challenge in synthetic organic chemistry and is "one of the most challenging fields in modern synthesis". ${ }^{1}$ In contrast, such reactions are rapid and efficient in nature. Metabolic pathways often involve aromatic hydroxylases and such enzymes could be potentially engineered and exploited for chemo-synthetic processes. In particular flavin dependant mono-oxygenases (FMOs) are attractive candidates for industrial aromatic hydroxylation. ${ }^{2}$ For example, an FMO from Pseudomonas azelaica (2-hydroxybiphenyl 3-mono-oxygenase) was artificially re-engineered for a

${ }^{a}$ School, of Chemistry, University of Bristol, Cantock's Close, BS8 1TS, UK. E-mail: russell.cox@oci.uni-hannover.de

${ }^{b}$ Chemistry of Natural and Microbial Products Department, National Research Centre, Cairo, 12622, Egypt

${ }^{c}$ Chemistry Department, Faculty of Science, Al Baha University, 1988, Al Baha, Saudi Arabia

${ }^{d}$ Microbiology Department, Faculty of Pharmacy, Cairo University, Cairo, 11562, Egypt ${ }^{e}$ School of Biochemistry, University of Bristol, Medical Sciences Building, BS8 1TD, UK ${ }^{f}$ Institut für Organische Chemie, Leibniz Universität Hannover, Schneiderberg $1 B$, 30167, Hannover, Germany

$\dagger$ Electronic supplementary information (ESI) available. See DOI: 10.1039/c5ra06693j

\$ These authors contributed equally. large-scale production of 3-tert-butylcatechol, ${ }^{3}$ a precursor for many important chemicals and synthetically intractable targets.

The recent elucidation of the biosynthetic pathway for stipitatic acid led to the identification of a new FMO (TropB). ${ }^{4}$ This enzyme catalyses the oxidative dearomatisation of 3-methylorcinaldehyde 1 to produce a dienone 2 (Scheme 1A). This hydroxylation step is remarkably similar to one of the steps reported for the chemical synthesis of azaphilones and their analogues (Scheme 1B).,

The synthetic step requires extreme cold temperatures $(-70$ to $-10{ }^{\circ} \mathrm{C}$ ), hazardous reagents and relatively long reaction time $(30 \mathrm{~h})$. It would be advantageous if related transformations could be performed bio-catalytically using TropB or a related enzyme. This would obviate the utilisation of dangerous chemicals and challenging reaction conditions to facilitate the synthesis of key synthetic intermediates.

In our previous work, TropB was overproduced recombinantly in $E$. coli and purified by nickel affinity chromatography, eluted as a single SDS-PAGE band (see ESI $\dagger$ ). The purified protein was shown by UV-Vis spectrophotometry and LC-MS to possess a non-covalently bound FAD cofactor. Exogenous NADH or NADPH is required as an electron donor for in vitro activity. Kinetic analysis showed that the enzyme possesses a slight preference for NADPH. ${ }^{4}$ The enzyme was shown to hydroxylate 1 regio-selectively at $\mathrm{C}-3$ to give the $3 R$ configured product. Different substrates including 3-methylorsellinic acid 3 and a 
A<smiles>Cc1cc(O)c(C)c(O)c1C=O</smiles>

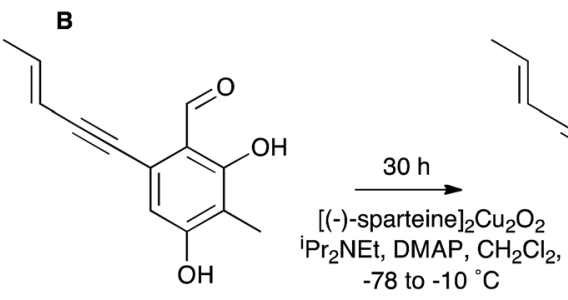

3

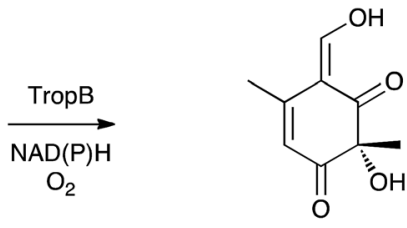

2
Scheme 1 (A) TropB catalysed reaction; (B) synthetic step reported for the synthesis of azaphilones.

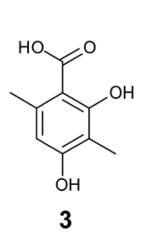<smiles>CC(=O)c1ccc(O)c(C)c1O</smiles>

4<smiles>Cc1cc(O)c(C)c(O)c1</smiles><smiles>Cc1cccc(C=O)c1O</smiles><smiles>CCc1cc(C=O)ccc1O</smiles><smiles>O=Cc1ccc(O)c(O)c1</smiles>

8

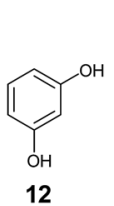

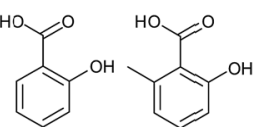

13
Fig. 1 Different compounds incubated with TropB

number of analogous compounds 4-14 (Fig. 1) were tested with TropB. Only the methyl ketone $\mathbf{4}$ was hydroxylated, whereas the other substrates were not. Here we extend these initial investigations by performing a detailed kinetic characterisation of TropB, to explore the enzyme's tolerance to a broad range of alternative aromatic substrates for example, compounds that differ in alkyl chain length and branching, and different substituents on the aromatic ring. Additionally, the effects of temperature and $\mathrm{pH}$ on the enzyme activity were also investigated in order to identify the optimum reaction conditions for TropB.

\section{Results and discussion}

\section{Overproduction of TropB and assay optimisation}

N-terminally hexahistidine tagged TropB was produced by recombinant overexpression in E. coli BL21-CodonPlus (DE3)$\mathrm{RP}$ and purified to homogeneity using a combination of $\mathrm{Ni}$ affinity and size exclusion chromatography (ESI Fig. S1†). The purified protein had a distinctive yellow colour and exhibited typical flavoprotein absorbance spectra with maxima at 368 and $455 \mathrm{~nm}$. These observations were consistent with those reported previously. ${ }^{4}$ No exogenous flavin was required to detect enzyme activity. The identity of the purified protein was confirmed by MALDI-TOF MS of a tryptic digest (see ESI $\dagger$ ).

The effect of temperature and $\mathrm{pH}$ on TropB activity was investigated using the enzyme's natural substrate, 3-methylorcinaldehyde 1 . This was to determine the optimum reaction conditions for later use during more detailed kinetic analyses. The enzyme was incubated with a fixed concentration of substrate $(200 \mu \mathrm{M})$ and NADPH $(100 \mu \mathrm{M})$ at different temperatures and appropriately buffered $\mathrm{pHs}$ and the initial rate of reaction measured.

TropB activity was monitored spectrophotometrically by following the formation of the reaction product at $400 \mathrm{~nm}$. The $\mathrm{pH}$ at which TropB was optimally active was $\mathrm{pH}$ 8.0. There was a considerable decrease in enzyme activity below $\mathrm{pH} 7$ or above pH 9 (Fig. 2A). The optimum temperature for Trop B activity was found to be $30{ }^{\circ} \mathrm{C}$ although surprisingly the enzyme did retain $40 \%$ of maximum activity at $60{ }^{\circ} \mathrm{C}$ (Fig. $2 \mathrm{~B}$ ).

\section{Synthesis of substrate analogues}

Compounds 15-27 (Fig. 3), were designed to probe the substrate selectivity of TropB in addition to the previously tested substrates. Metabolites 25-27 are natural products and were extracted from their natural sources according to established protocols. ${ }^{5,7}$ The analogues $\mathbf{4}$ and $\mathbf{8}$ were purchased from Sigma. The remaining compounds were produced synthetically.

Aryl alkyl ketones were obtained directly from Friedel-Crafts acylation using 2,5-dimethylresorcinol 9 with the appropriate acid chlorides in the presence of zinc powder as a catalyst (Scheme 2). ${ }^{8}$ The yield of desired products was very low $(<5 \%)$. This was unsurprising given the presence of unprotected

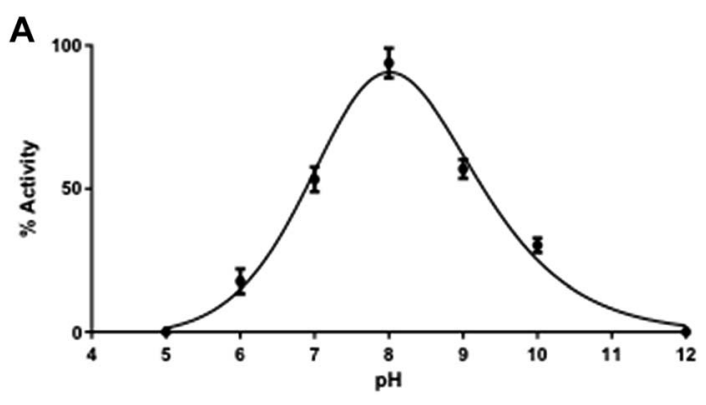

B

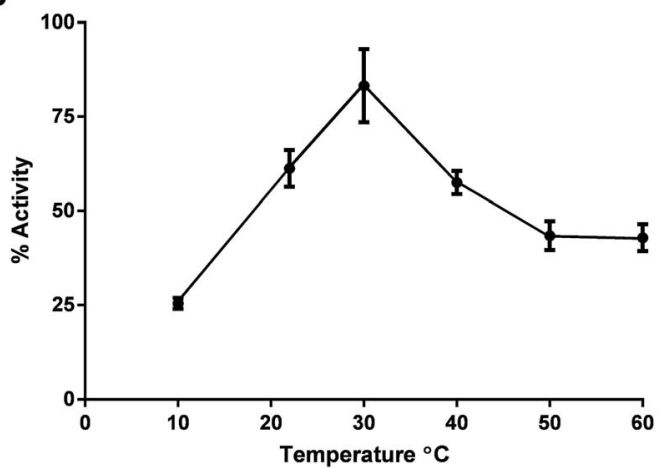

Fig. 2 The relative effect of (A) $\mathrm{pH}$ and (B) temperature on TropB activity with 3-methylorcinaldehyde 1. 
<smiles>CC(=O)c1c(C)cc(O)c(C)c1O</smiles>

15<smiles>COc1ccc(C(=O)c2c(C)cc(O)c(C)c2O)c(OC)c1</smiles>

21<smiles>CCC(=O)c1c(C)cc(O)c(C)c1O</smiles>

16<smiles>Cc1cc(O)c(C)c(O)c1[N+](=O)[O-]</smiles>

22<smiles>CCCC(=O)c1c(C)cc(O)c(C)c1O</smiles>

17<smiles>CCC(C)C(=O)c1c(C)cc(O)c(C)c1O</smiles>

18<smiles>Cc1cc(O)c(C)c(O)c1N=O</smiles>

23<smiles>Cc1c(O)c([N+](=O)[O-])c(C)c([N+](=O)[O-])c1O</smiles>

24<smiles>[3H]CCCCCC(=O)c1c(C)cc(O)c(C)c1O</smiles>

19<smiles>Cc1c(O)c(C)c(O)c(C=O)c1O</smiles>

25<smiles>Cc1cc(O)c(C)c(O)c1C(=O)c1ccccc1</smiles>

20

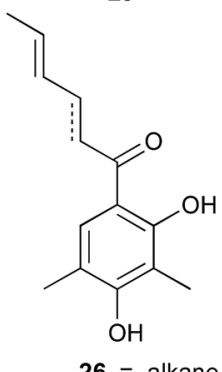

26 = alkane $\mathbf{2 7}$ = alkene

Fig. 3 Structures of the compounds for evaluating the substrate selectivity of TropB.

hydroxyl groups within 9 leading to the formation of many side products which were detected by LC-DAD-MS. However, the desired products were easily identified by their mass and UV absorption which was higher than those of the oxygen-acylated side products. As the aim was to rapidly produce only a few milligrams of material for enzyme assays the low yields were not problematic. The only exception was for $\mathbf{1 5}$ where it was not possible to generate enough material for full kinetic analysis.

The syntheses of 4-nitro-2,5-dimethylresorcinol 22 and 4,6dinitro-2,5-dimethylresorcinol 24 were achieved by the mono and di-nitration of $\mathbf{9}$ using a mixture of diluted nitric acid and acetic anhydride., ${ }^{\mathbf{9}, 10}$ The 4-nitroso-2,5-dimethylresorcinol compound 23 was synthesised using diluted sulphuric acid and sodium nitrite following a previously reported synthesis. ${ }^{11}$

All the compounds were purified using preparative LC-MS and the structure of each was confirmed by high resolution mass spectrometry and NMR. To the best of our knowledge none of these compounds have previously been characterised and only 23 and 15 had previously been synthesised. ${ }^{\mathbf{1 0 , 1 2}}$ Characterisation of compounds is given in the ESI. $\dagger$

\section{Substrate selectivity}

TropB and its potential substrates $(2.5 \mathrm{mM})$ were incubated for 1 hour with an excess of NADPH $(3.0 \mathrm{mM})$ at $\mathrm{pH} 8$ and $30{ }^{\circ} \mathrm{C}$.

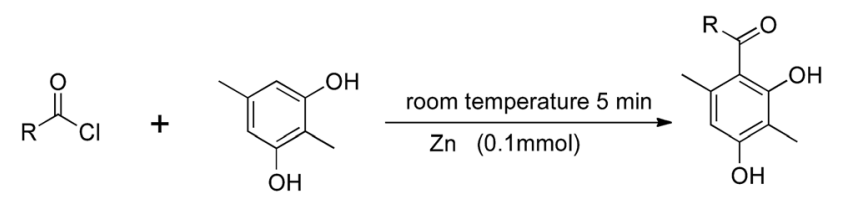

$(0.11 \mathrm{mmol})$

$(0.10 \mathrm{mmol})$

Scheme 2 Friedel-Crafts acylation using acyl chlorides with aromatic compounds and $\mathrm{Zn}$ powder.
LCMS analysis was used to detect the presence of reaction products. Control experiments with heat-denatured protein were also performed. Compounds which were demonstrated as substrates by TropB in this assay were then taken forward for full kinetic characterisation. All kinetic assays were performed using a continuous spectrophotometric assay monitoring either product formation at $400 \mathrm{~nm}$ or conversion of NADPH to NADP ${ }^{+}$ at $340 \mathrm{~nm}$ (Table 1) to determine the initial rate.

TropB was found to catalyse the NADPH dependent conversion of the natural substrate 3-methylorcinaldehyde 1 to the dienone 2 with a $k_{\text {cat }}$ of $0.298 \pm 0.006 \mathrm{~s}^{-1}$. This compares unfavourably to other FMO enzymes such as 2-methyl-3hydroxypyridine-5-carboxylic-acid dioxygenase ${ }^{\mathbf{1 3 , 1 4}}$ (MHPCO) which has a $k_{\text {cat }}$ of $11.8 \mathrm{~s}^{-1}$ and 3-hydroxybenzoate 6-hydroxylase $^{14}(3 \mathrm{HB} 4 \mathrm{H})$ which has a $k_{\text {cat }}$ of $36 \mathrm{~s}^{-1}$. However, the $K_{\mathrm{M}}$ determined for TropB $(20.0 \pm 1.42 \mu \mathrm{M})$ is similar to the values published for MHPCO $(25.4 \mu \mathrm{M})$ and $3 \mathrm{HB} 4 \mathrm{H}(27 \mu \mathrm{M})$.

The acetophenone derivative 4 is turned over by the enzyme at a similar rate to the natural substrate but binds more weakly as indicated by a 9-fold increase in $K_{\mathrm{M}}$. This is probably due to the missing 6-methyl group because compounds 16 and 17 which retain the 6-methyl group have lower $K_{\mathrm{M}}$ values than 4 . The fact that these $K_{\mathrm{M}}$ values are still higher than the natural substrate is probably due to steric hindrance from the longer carbon chains. This less than optimal binding was probably the reason for the lower $k_{\text {cat }}$ values. Compound 8 which lacks both methyl groups was not accepted by the enzyme.

Compounds 18-21 which have long or branched alkyl ketone chains and aryls on the C-1 position are not well tolerated by the enzyme and yielded un- or barely-detectable levels of reaction product. The nitro and nitroso derivatives 22 and 23 were accepted as substrates but the turnover was slower than for the natural substrate and was similar to compounds 16 and 17. The $K_{\mathrm{M}}$ value for these compounds was higher than the natural 
Table 1 Substrate tolerance and kinetic parameters of TropB with the substrates tested. All kinetic assays were done in triplicate. "Trace" means the amount of product detected was at the lower limit of detection. Errors show standard deviation. n.d. not determined

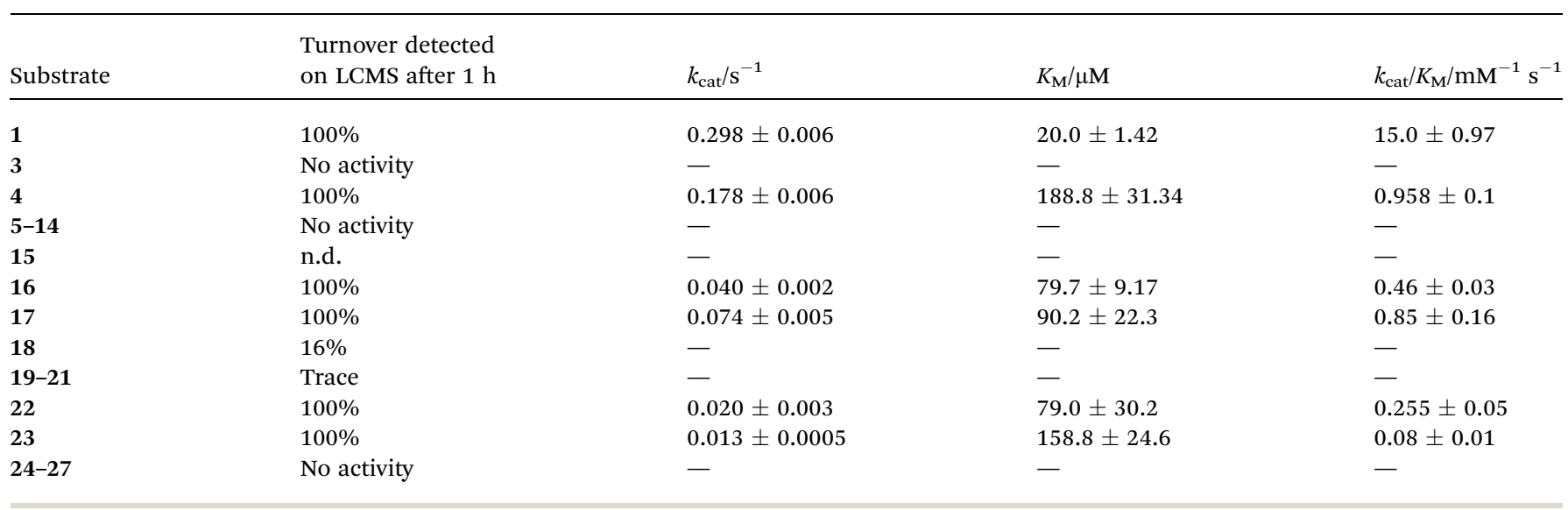

substrate and nitroso had a higher $K_{\mathrm{M}}$ than the nitro analogue. 26 and 27 are substrates for SorbC, a homologue of TropB, and these were chosen for analysis along with 24 and $25 .^{7}$ These compound were not substrates for TropB.

Attempts to further purify and characterise the oxidation products failed, since they were not stable in organic solvents. ${ }^{15}$ However oxidation of the nitroso compound $\mathbf{2 3}$ resulted in the formation of the stable oxime 28 (Fig. 4). The reaction using 23 was scaled up to $16 \mathrm{ml}$ and the product 28 purified by LC-MS. Seven milligrams of the product (99\%) was obtained as a colourless oil. The molecular formula $\mathrm{C}_{8} \mathrm{H}_{9} \mathrm{NO}_{4}$ was deduced from the HRMS data (found: $206.0425[\mathrm{M}] \mathrm{Na}^{+}$; calcd: 206.0429 for $\mathrm{C}_{8} \mathrm{H}_{9} \mathrm{NNaO}_{4}$ ). Analysis of the ${ }^{1} \mathrm{H}$ and ${ }^{13} \mathrm{C}$-NMR spectra of the product demonstrated that oxidation occurred via hydroxylation at C-2 of the benzenoid ring (see ESI $\uparrow$ for data).

In an attempt to rationalise, the substrate selectivity of TropB a homology model of the enzyme was generated. TropB shows $25 \%$ identity to the FAD-dependent 3-hydroxybenzoate 6hydroxylase (HB6H) from Rhodococcus jostii RHA1 for which a crystal structure has been obtained (pdb accession $4 \mathrm{bjy}){ }^{16}$ This was used as a template for the development of a threaded model structure using the SWISS-MODEL protein structure homologymodelling server. The FAD cofactor was placed into the active site of the homology model by transferring the coordinates from the template (4bjy) into the homology model and subjecting the protein-ligand complex to energy minimisation.
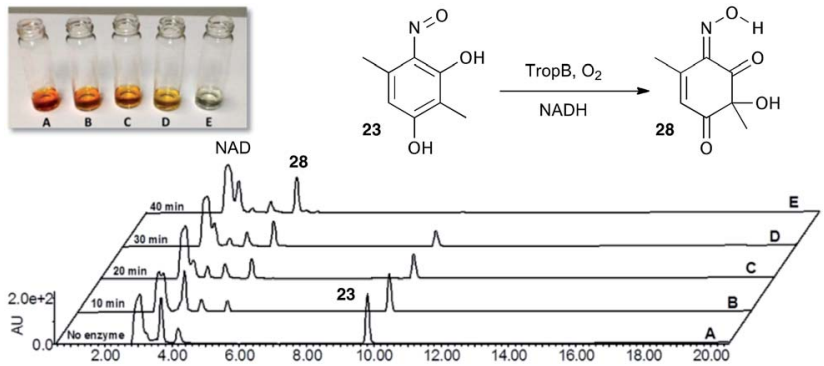

Fig. 4 Conversion of 23 to 28 by TropB over 40 minutes showing consumption of 23 and formation of 28 .
To determine the substrate binding mode and possible catalytic mechanism, a sequence alignment was made between TropB and HB6H (Fig. 5). Two residues involved in substrate interactions in 4 bjy are conserved in TropB and could play similar roles. These are Y217 (= Y239) which H-bonds to the C1 substituent and $\mathrm{H} 213(=\mathrm{H} 235)$ which was proposed to act as a base to deprotonate the phenolic hydroxyl. The latter was shown to be essential for catalysis in HB6H by mutagenesis studies.

The TropB substrate $\mathbf{1}$ was manually docked into the homology model near the FAD in an orientation consistent with the known stereo-chemical outcome of the reaction. ${ }^{4}$ The resulting protein-ligand complex was energy minimised using the YASARA algorithm (Fig. 6). P329 and I237 make hydrophobic interactions with the substrate and F252 directly interacts with substrate 6-methyl group. $\mathrm{N} 248$ is also within $\mathrm{H}$ bonding distance of the carbonyl oxygen $(2.4 \AA)$. The substrate and FAD are orientated approximately perpendicular to each other which is similar to the arrangement of these moieties in HB6H. ${ }^{17}$

Y239 is located near the 2-hydroxy of the substrate $(2.4 \AA)$ and the carbonyl oxygen $(1.9 \AA)$, while $\mathrm{H} 235$ is near the substrate 4-hydroxy (within $4.5 \AA$ ). These two residues could therefore play a role in catalysis (Scheme 3). Deprotonation of the 4-hydroxy by $\mathrm{H} 235$ would increase the nucleophilicity of the 3-carbon thus aiding in its attack of the FAD hydroperoxide. The tyrosine could then act as a general acid protonating the resulting alkoxide during or after reaction. Such an acid-base mechanism would be consistent with the pH profile (Fig. 2) which shows an optimum at $\mathrm{pH}$ 8.0.

This mechanism would also be consistent with TropB accepting nitro and nitroso derivatives and would provide an explanation for why TropB rejects the carboxylate derivative 3 as

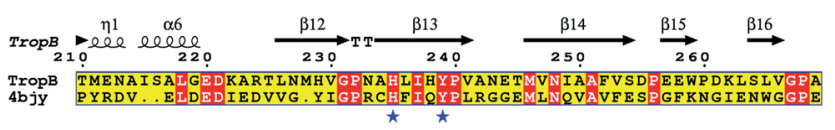

Fig. 5 Alignment of TropB and HB6H (4bjy) showing the conserved $\mathrm{His}$ and Tyr residues involved in substrate interactions. 


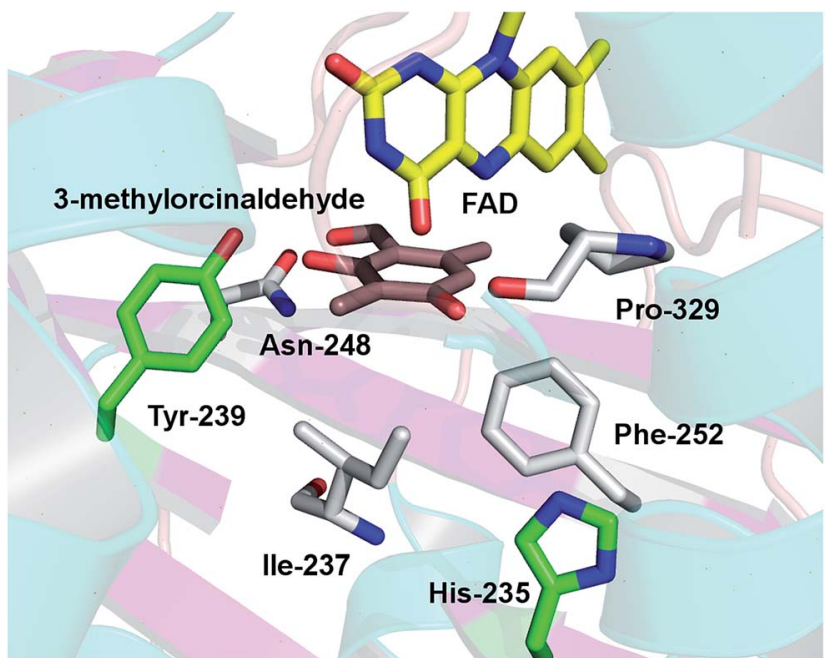

Fig. 6 Docking of 3-methylorcinaldehyde inside the active site of the TropB homology model. His-235 and Tyr-239 are conserved from the template (4bjy). His235 to $\mathrm{H}$ (hydroxyl) = either $4.5 \mathrm{~A}$ or $6.2 \AA$ depending on the orientation of the $\mathrm{H}$. After energy minimisation the $\mathrm{H}$ is $6.2 \AA$ away from the His but if the $\mathrm{H}$ is rotated to point towards the His then this is reduced to $4.5 \AA$. Colour scheme: yellow, cofactor; green potential catalytic residues; grey; hydrophobic and $\mathrm{H}$-bonding interactions.
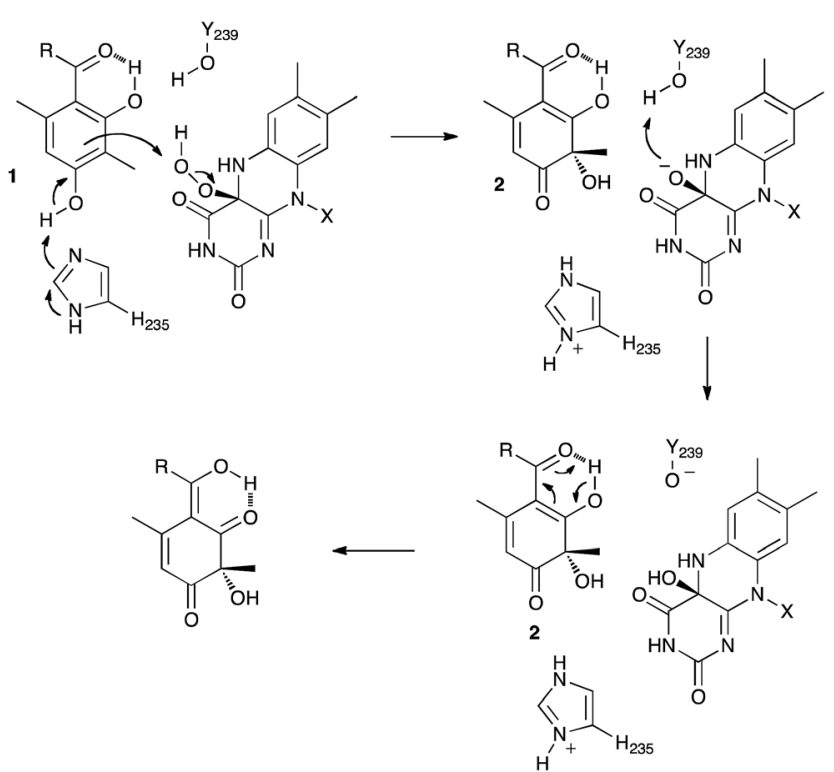

Scheme 3 Possible mechanism for the hydroxylation of 1 catalysed by TropB.

the carboxylate ion would make deprotonation of the phenolic hydroxyl groups by $\mathrm{H} 235$ more difficult.

Consistent with our kinetic analyses, the active site in our model is large enough to accommodate alkyl chains of up to 3 carbons beyond the carbonyl oxygen (Fig. 7), but not the bulkier aromatic substrates. Interestingly, docking of bromoalkyl substrate 19 shows that the active site pocket could reorganise to increase the available volume for some substrates, although

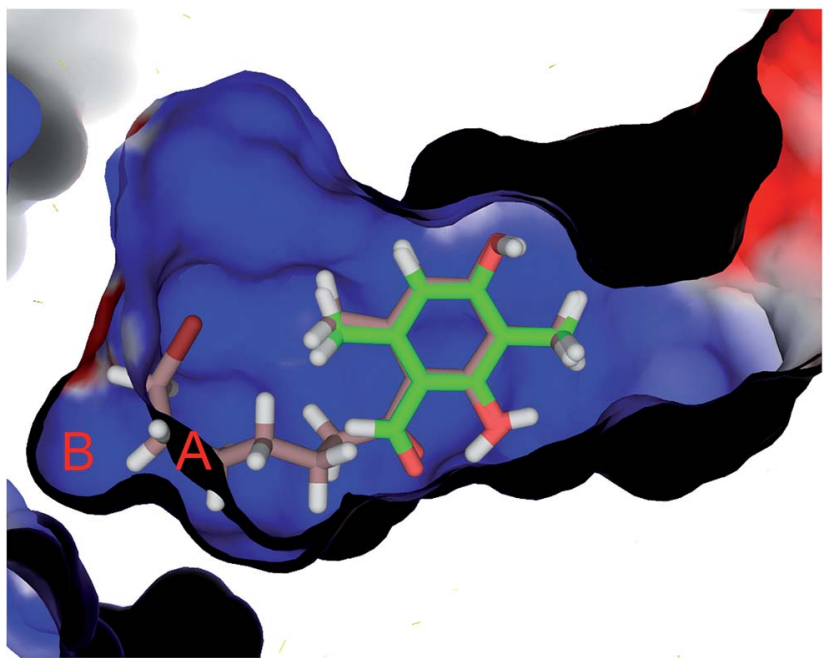

Fig. 7 Active site surface of TropB homology model coloured according to electrostatic potential. (A) shows the boundary of the active site surface when the natural substrate (green) was docked. This active site could accommodate up to 3 carbons beyond the carbonyl oxygen. (B) shows the extra space opened up by conformational change during energy minimisation when 19 (grey) was docked.

this is clearly not sufficient to allow 19 or the aromatic substrates $\mathbf{2 0}$ and $\mathbf{2 1}$ to be efficient substrates. The active site surface also appears to be highly charged and thus is not favourable for binding hydrophobic groups. The kinetic data showed a role for the 6-methyl group in binding and the model shows this group interacts with F252, possibly fixing the substrate in the correct orientation for effective deprotonation by $\mathrm{H} 235$.

\section{Conclusions}

In summary, we have identified the optimum reaction conditions for the FAD dependent monooxygenase TropB and probed the substrate selectivity of this enzyme using a range of newly synthesised substrate analogues. We have identified the key role of a 6-methyl group for substrate binding within the TropB active site. Nitro and nitroso containing substrates are tolerated by the enzyme as are aryl alkyl ketones with chains of 4 carbons or less. Substrates containing branched chains and bicyclic systems are not tolerated. These insights will be of value in guiding the design of new TropB substrates for enzymatic conversion to high-value chemicals and future efforts to engineer the substrate selectivity of these enzymes, thus illustrating the potential utility of TropB as a potential biocatalyst.

\section{Experimental}

\section{Chemicals}

FAD, NADPH, 2,4-dihydroxy-3,5-dimethylacetophenone and 2,4dihydroxy benzaldehyde were purchased from Sigma. NMR was performed using a Varian VNMRS 400 or Varian VNMRS 500 spectrometer. High resolution mass spectrometry was achieved with a Bruker Daltonics Apex IV FT-ICR. 


\section{Bioinformatic analysis}

Similar amino acid sequences were identified by a BLASTP search (http://blast.ncbi.nlm.nih.gov). Multiple sequence alignments of TropB were performed using Multalin (http:// multalin.toulouse.inra.fr/multalin/) ${ }^{17}$ and formatted by ESPript (http://espript.ibcp.fr/ESPript/ESPript/). ${ }^{18}$

\section{Isolation of natural products}

3-Methylorcinaldehyde 1 and 5-hydroxy-3-methylorcin-aldehyde 25 were isolated from $T$. stipitatus knockout strains $\Delta t s L 1$ and the dienone 2 was isolated from $\Delta t s R 5$ by LC-MS as described before. ${ }^{8}$ Dihydrosorbicillin 26 and 2,3-sorbicillin 27 were isolated from Penicillium chrysogenum as described before. ${ }^{7}$

\section{Chemical synthesis}

Aryl alkyl ketones. Aryl alkyl ketones were synthesised by Friedel-Crafts acylation using acyl chlorides and aromatic compounds according to established protocol. ${ }^{9}$ The reaction was performed on a small scale with $13.8 \mathrm{mg}(0.1 \mathrm{mmol})$ of 2,5dimethyl-resorcinol and $6.5 \mathrm{mg}(0.1 \mathrm{mmol})$ of very fine zinc powder in a $5 \mathrm{ml}$ reaction vial. Particles were ground together using a small glass stirring rod before the addition of $0.11 \mathrm{mmol}$ of an alkyl or aryl acyl chloride. This was mixed for 5 minutes at room temperature. The reaction was quenched with $2 \mathrm{ml}$ of methanol. The solution was filtered and subjected directly to LC-DAD-MS for analysis and purification.

1-Acetyl-2,4-dihydroxy-3,6-dimethylbenzene 15 (ref. 19). White needles; 5\% yield; m.p. $152{ }^{\circ} \mathrm{C}$ (lit. $\left.{ }^{20} 149-150{ }^{\circ} \mathrm{C}\right) ; \mathrm{UV}\left(\mathrm{CH}_{3} \mathrm{CN} /\right.$ $\mathrm{H}_{2} \mathrm{O}$ ), $\lambda_{\max } 222$ and $290 \mathrm{~nm}$; IR (neat): $\nu_{\max } 3397,1598,1457$, 1415, 1227 and $1117 \mathrm{~cm}^{-1}$; ${ }^{1} \mathrm{H}-\mathrm{NMR}\left(400 \mathrm{MHz}, \mathrm{CD}_{3} \mathrm{CN}\right) \delta_{\mathrm{H}}=$ 13.82 (br, 1H, 2-OH), 6.27 (s, 1H, 5-H), 2.59 (s, 3H, 10-H), $2.52(\mathrm{~s}$, $3 \mathrm{H}, 8-\mathrm{H}), 1.98(3 \mathrm{H}, \mathrm{s}, 7-\mathrm{H}) ;{ }^{13} \mathrm{C}-\mathrm{NMR}\left(100 \mathrm{MHz}, \mathrm{CD}_{3} \mathrm{CN}\right) \delta_{\mathrm{C}}=$ 206.0 (C-9), 165.5 (C-2), 160.9 (C-4), 140.8 (C-6), 115.5 (C-1), 111.8 (C-5), 109.8 (C-3), 33.4 (C-10), 25.0 (C-8), 7.9 (C-7); HRMS for $\mathrm{C}_{10} \mathrm{H}_{13} \mathrm{O}_{3}$ calcd: 181.0865; found: $181.0860[\mathrm{M}] \mathrm{H}^{+}$.

1-Propionyl-2,4-dihydroxy-3,6-dimethylbenzene 16. White needles, $4 \%$ yield; m.p. $88^{\circ} \mathrm{C}$; IR (neat): $\nu_{\max } 3397,1601,1420,1236$, 1108 and $1075 \mathrm{~cm}^{-1}$; $\mathrm{UV}\left(\mathrm{CH}_{3} \mathrm{CN} / \mathrm{H}_{2} \mathrm{O}\right) \lambda_{\max } 222$ and $286 \mathrm{~nm} ;{ }^{1} \mathrm{H}-$ NMR (400 MHz, CD $\left.{ }_{3} \mathrm{CN}\right) \delta_{\mathrm{H}}=13.50(\mathrm{br}, 1 \mathrm{H}, 2-\mathrm{OH}), 6.29(\mathrm{~s}, 1 \mathrm{H}$, 5-H), $2.96(\mathrm{~m}, 2 \mathrm{H}, 10-\mathrm{H}), 2.51(3 \mathrm{H}, \mathrm{s}, 8-\mathrm{H}), 1.98(3 \mathrm{H}, \mathrm{s}, 7-\mathrm{H}), 1.13$ $\left(\mathrm{t},{ }^{3} J=7.07,3 \mathrm{H}, 11-\mathrm{H}\right) ;{ }^{13} \mathrm{C}-\mathrm{NMR}\left(100 \mathrm{MHz}, \mathrm{CD}_{3} \mathrm{CN}\right) \delta_{\mathrm{C}}=209.0$ (C-9), 164.8 (C-2), 160.4 (C-4), 140.0 (C-6), 115.6 (C-1), 111.8 (C5), 109.8 (C-3), 37.9 (C-10), 25.1 (C-8), 9.1 (C-11), 7.9 (C-7); HRMS for $\mathrm{C}_{11} \mathrm{H}_{15} \mathrm{O}_{3}$ calcd: 195.1021; found: $195.1026[\mathrm{M}] \mathrm{H}^{+}$.

1-Butanoyl-2,4-dihydroxy-3,6-dimethylbenzene 17. White needles, 5\% yield; m.p. $110{ }^{\circ} \mathrm{C}$; IR (neat): $\nu_{\max }$ 3457, 1598, 1403, 1300, 1207 and $1111 \mathrm{~cm}^{-1}$; UV $\left(\mathrm{CH}_{3} \mathrm{CN} / \mathrm{H}_{2} \mathrm{O}\right) \lambda_{\max } 223$ and 288 $\mathrm{nm} ;{ }^{1} \mathrm{H}-\mathrm{NMR}\left(400 \mathrm{MHz}, \mathrm{CDCl}_{3}\right.$ ) $\delta_{\mathrm{H}}=13.54(\mathrm{br}, 1 \mathrm{H}, 2-\mathrm{OH}), 6.20$ (s, 1H, 5-H), $2.88\left(\mathrm{t},{ }^{3} J=7.30,2 \mathrm{H}, 10-\mathrm{H}\right), 2.54(3 \mathrm{H}, \mathrm{s}, 8-\mathrm{H}), 2.09$ $(3 \mathrm{H}, \mathrm{s}, 7-\mathrm{H}), 1.76(\mathrm{~m}, 2 \mathrm{H}, 11-\mathrm{H}), 0.98\left(\mathrm{t},{ }^{3} \mathrm{~J}=7.40,3 \mathrm{H}, 12-\mathrm{H}\right) ;{ }^{13} \mathrm{C}-$ NMR (100 MHz, CDCl $\left.{ }_{3}\right) \delta_{\mathrm{C}}=207.4$ (C-9), 164.2 (C-2), 158.2 (C-4), 138.6 (C-6), 115.6 (C-1), 109.1 (C-3), 111.1 (C-5), 46.1 (C-10), 25.0 (C-8), 18.6 (C-11), 14.0 (C-12), 7.7 (C-7); HRMS for $\mathrm{C}_{12} \mathrm{H}_{17} \mathrm{O}_{3}$ calcd: 209.1178; found: $209.1176[\mathrm{M}] \mathrm{H}^{+}$. \pm 1-(2-Methylbutanoyl)-2,4-dihydroxy-3,6-dimethylbenzene 18. White needles, $3 \%$ yield; m.p. $90{ }^{\circ} \mathrm{C}$; IR (neat): $\nu_{\max } 3367,1598$, 1457, 1415, 1227 and $1117 \mathrm{~cm}^{-1}$; $\mathrm{UV}\left(\mathrm{CH}_{3} \mathrm{CN} / \mathrm{H}_{2} \mathrm{O}\right) \lambda_{\max } 223$ and $291 \mathrm{~nm} ;{ }^{1} \mathrm{H}-\mathrm{NMR}\left(500 \mathrm{MHz}, \mathrm{CDCl}_{3}\right) \delta_{\mathrm{H}}=12.74$ (br, $\left.1 \mathrm{H}, 2-\mathrm{OH}\right)$, $6.21(\mathrm{~s}, 1 \mathrm{H}, 5-\mathrm{H}), 2.88(\mathrm{~m}, 1 \mathrm{H}, 10-\mathrm{H}), 2.53(3 \mathrm{H}, \mathrm{s}, 8-\mathrm{H}), 2.09(3 \mathrm{H}$, s, 7-H), $1.79(\mathrm{~m}, 1 \mathrm{H}, 11-\mathrm{Hb}), 1.46(\mathrm{~m}, 1 \mathrm{H}, 11-\mathrm{Ha}), 1.17\left(\mathrm{~d},{ }^{3} J=\right.$ 6.7, 3H, 13-H), $0.88\left(\mathrm{t},{ }^{3} \mathrm{~J}=7.4,3 \mathrm{H}, 12-\mathrm{H}\right) ;{ }^{13} \mathrm{C}-\mathrm{NMR}(125 \mathrm{MHz}$, $\left.\mathrm{CDCl}_{3}\right) \delta_{\mathrm{C}}=212.6(\mathrm{C}-9), 163.1(\mathrm{C}-2), 158.0(\mathrm{C}-4), 137.6$ (C-6), 116.1 (C-1), 111.0 (C-5), 109.0 (C-3), 46.0 (C-10), 27.9 (C-11), 24.0 (C-8), 17.1 (C-13), 12.0 (C-12), 7.7 (C-7); HRMS for $\mathrm{C}_{13} \mathrm{H}_{19} \mathrm{O}_{3}$ calcd: 223.1334; found: $223.1330[\mathrm{M}] \mathrm{H}^{+}$.

1-(6-Bromohexanoyl)-2,4-dihydroxy-3,6-dimethylbenzene 19. White needles, $4 \%$ yield; m.p. $94-96{ }^{\circ} \mathrm{C}$; IR (neat): $\nu_{\max } 3376$, 1729, 1601, 1415, 1117 and $746 \mathrm{~cm}^{-1}$; UV $\left(\mathrm{CH}_{3} \mathrm{CN} / \mathrm{H}_{2} \mathrm{O}\right) \lambda_{\max }$ 222 and $289 \mathrm{~nm} ;{ }^{1} \mathrm{H}-\mathrm{NMR}\left(400 \mathrm{MHz}, \mathrm{CDCl}_{3}\right) \delta_{\mathrm{H}}=13.51$ (br, 1H, 2-OH), 6.21 (s, 1H, 5-H), $3.43\left(\mathrm{t},{ }^{3} J=6.6,2 \mathrm{H}, 14-\mathrm{H}\right)$, $2.92\left(\mathrm{t},{ }^{3} J=7.3,2 \mathrm{H}, 10-\mathrm{H}\right), 2.53(3 \mathrm{H}, \mathrm{s}, 8-\mathrm{H}), 2.09(3 \mathrm{H}, \mathrm{s}, 7-\mathrm{H})$, $1.90(\mathrm{~m}, 2 \mathrm{H}, 13-\mathrm{H}), 1.76(\mathrm{~m}, 2 \mathrm{H}, 11-\mathrm{H}), 1.51(\mathrm{~m}, 2 \mathrm{H}, 12-\mathrm{H})$;

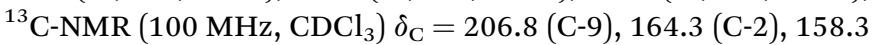
(C-4), 138.5 (C-6), 115.5 (C-1), 111.2 (C-5), 109.1 (C-3), 43.9 (C-10), 33.8 (C-14), 32.8 (C-13), 28.0 (C-12), 25.1 (C-8), 24.2 (C-11), 7.7 (C-7); HRMS for $\mathrm{C}_{14} \mathrm{H}_{20} \mathrm{BrO}_{3}$ calcd: 315.0596; found: $315.0602[\mathrm{M}] \mathrm{H}^{+}$.

1-Benzoyl-2,4-dihydroxy-3,6-dimethylbenzene 20. Colourless needles, 3\% yield; m.p. $145{ }^{\circ} \mathrm{C}$; UV $\left(\mathrm{CH}_{3} \mathrm{CN} / \mathrm{H}_{2} \mathrm{O}\right) \lambda_{\max } 203,248$ and $304 \mathrm{~nm} ;{ }^{1} \mathrm{H}-\mathrm{NMR}\left(400 \mathrm{MHz}, \mathrm{CDCl}_{3}\right) \delta_{\mathrm{H}}=12.74(\mathrm{br}, 1 \mathrm{H}, 2-$ $\mathrm{OH}), 7.59\left(\mathrm{dd},{ }^{3} \mathrm{~J}=8.4,{ }^{5} \mathrm{~J}=1.2,2 \mathrm{H}, 11-\mathrm{H}\right.$ and $\left.15-\mathrm{H}\right), 7.53\left(\mathrm{tt},{ }^{3} \mathrm{~J}=\right.$ $\left.7.4,{ }^{4} J=1.4,1 \mathrm{H}, 13 \mathrm{H}\right), 7.44(\mathrm{~m}, 2 \mathrm{H}, 12-\mathrm{H}$ and $14-\mathrm{H}), 6.20(\mathrm{~s}, 1 \mathrm{H}$, 5-H), 2.16 (3H, s, 7-H), 1.84 (3H, s, 8-H); ${ }^{13} \mathrm{C}-\mathrm{NMR}(100 \mathrm{MHz}$, $\left.\mathrm{CDCl}_{3}\right) \delta_{\mathrm{C}}=201.8(\mathrm{C}-9), 161.6(\mathrm{C}-2), 158.5(\mathrm{C}-4), 141.6(\mathrm{C}-10)$, 138.9 (C-6), 132.1 (C-13) 128.7 (C-11 and C-15), 128.6 (C-12 and C-14), 115.7 (C-1), 110.5 (C-5), 108.8 (C-3), 23.4 (C-8), 7.7 (C-7); HRMS for $\mathrm{C}_{15} \mathrm{H}_{15} \mathrm{O}_{3}$ calcd: 243.1021; found: $243.1032[\mathrm{M}] \mathrm{H}^{+}$.

1-(2,4-Dimethoxybenzoyl)-2,4-dihydroxy-3, 6-dimethylbenzene 21. Colourless needles, $2 \%$ yield; m.p. $155{ }^{\circ} \mathrm{C}$; $\mathrm{UV}\left(\mathrm{CH}_{3} \mathrm{CN} / \mathrm{H}_{2} \mathrm{O}\right) \lambda_{\max }$ 204 and $304 \mathrm{~nm} ;{ }^{1} \mathrm{H}-\mathrm{NMR}\left(500 \mathrm{MHz}, \mathrm{CD}_{3} \mathrm{CN}\right) \delta=12.65$ (br, $1 \mathrm{H}, 2-$ $\mathrm{OH}), 7.16\left(\mathrm{~d},{ }^{3} \mathrm{~J}=8.7,1 \mathrm{H}, 15-\mathrm{H}\right), 6.59\left(\mathrm{dd},{ }^{3} \mathrm{~J}=8.7,{ }^{4} \mathrm{~J}=2.5,1 \mathrm{H}, 14-\right.$ $\mathrm{H}), 6.58(\mathrm{~s}, 1 \mathrm{H}, 12-\mathrm{H}), 6.19$ (s, 1H, 5-H), $3.84(\mathrm{~s}, 3 \mathrm{H}, 17-\mathrm{H}), 3.72(\mathrm{~s}$, $3 \mathrm{H}, 16-\mathrm{H}), 1.80(3 \mathrm{H}, \mathrm{s}, 8-\mathrm{H}), 1.47$ (3H, s, 7-H); ${ }^{13} \mathrm{C}-\mathrm{NMR}(125 \mathrm{MHz}$, $\mathrm{CD}_{3} \mathrm{CN}$ ) $\delta=201.0$ (C-9), 164.1 (C-2), 164.0 (C-13), 161.1 (C-4), 158.9 (C-11), 140.9 (C-6), 130.7 (C-15), 126.0 (C-10), 116.5 (C-1), 111.4 (C-5), 109.6 (C-3), 106.3 (C-14), 99.6 (C-12), 56.5 (C-17), 56.3 (C-16), 22.5 (C-8), 7.9 (C-7); HRMS for $\mathrm{C}_{15} \mathrm{H}_{15} \mathrm{O}_{3}$ calcd: 303.1232; found: $303.1239[\mathrm{M}] \mathrm{H}^{+}$.

1-Nitro-2,4-dihydroxy-3,6-dimethylbenzene 22. The mononitration of 2,5-dimethylresorcinol was achieved with a mixture of diluted nitric acid and acetic anhydride at room temperature. ${ }^{10,11}$ TLC and LC-MS was used to monitor the reaction until it reached $70 \%$ completion. The mixture was further diluted and extracted with ethyl acetate. The crude extract was dissolved in methanol and purified by mass-directed LC-MS.

Yellow amorphous solid; $70 \%$ yield; m.p. $130{ }^{\circ} \mathrm{C}$ IR (neat): $\nu_{\max } 3440,1625,1604,1340$ and 1194; $\mathrm{UV}\left(\mathrm{CH}_{3} \mathrm{CN} / \mathrm{H}_{2} \mathrm{O}\right) \lambda_{\max } 344$ $\mathrm{nm} ;{ }^{1} \mathrm{H}-\mathrm{NMR}\left(500 \mathrm{MHz}, \mathrm{CD}_{3} \mathrm{CN}\right) \delta_{\mathrm{H}}=6.38(\mathrm{~s}, 1 \mathrm{H}, 6-\mathrm{H}), 2.51$ (s, 3H, 8-H), 2.05 (3H, s, 7-H); ${ }^{13} \mathrm{C}-\mathrm{NMR}\left(125 \mathrm{MHz}, \mathrm{CD}_{3} \mathrm{CN}\right)$ 
$\delta_{\mathrm{C}}=161.7(\mathrm{C}-1), 157.3(\mathrm{C}-3), 137.3(\mathrm{C}-5), 130.0(\mathrm{C}-4), 112.4(\mathrm{C}-6)$, 111.4 (C-2), 23.1 (C-8), 8.4 (C-7).

1-Nitroso-2,4-dihydroxy-3,6-dimethylbenzene 23 (ref. 13). The mono-nitrosation of 2,5-dimethylresorcinol was achieved using diluted sulphuric acid and sodium nitrite. ${ }^{\mathbf{1 2}}$ Diluted sulphuric acid ( $1 \mathrm{ml} \mathrm{H}_{2} \mathrm{SO}_{4}$ in $40 \mathrm{ml}$ water) was added drop wise over a vigorously stirred solution of 2,5-dimethylresorcinol (138 mg, 1 $\mathrm{mmol}$ ) and sodium nitrite $(140 \mathrm{mg}, 2 \mathrm{mmol})$ in $10 \mathrm{ml}$ aqueous ethanol $50 \%$. The formation was monitored using TLC and LCMS during the addition of diluted acid until the reaction reached to $80 \%$ completion. The reaction was diluted with 300 $\mathrm{ml}$ water and extracted by ethyl acetate. The crude extract was dissolved in methanol and the compounds purified by massdirected LC-MS.

Red amorphous solid; 80\% yield; m.p. $164{ }^{\circ} \mathrm{C}$; IR (neat): $\nu_{\max }$ 3200, 2925, 1623, 1407, 1321, 1137, 1082 and 874; UV $\left(\mathrm{CH}_{3} \mathrm{CN} /\right.$ $\left.\mathrm{H}_{2} \mathrm{O}\right) \lambda_{\max } 210$ and $303 \mathrm{~nm} ;{ }^{1} \mathrm{H}-\mathrm{NMR}\left(500 \mathrm{MHz}, \mathrm{CD}_{3} \mathrm{CN}\right) \delta_{\mathrm{H}}=$ 6.38 (s, 1H, 6-H), 2.35 (s, 3H, 8-H), 1.85 (3H, s, 7-H); ${ }^{13} \mathrm{C}-\mathrm{NMR}$ (125 MHz, CD $\left.{ }_{3} \mathrm{CN}\right) \delta_{\mathrm{C}}=171.1$ (C-1), 169.8 (C-3), 150.1 (C-4), 143.2 (C-5), 119.0 (C-6), 111.5 (C-2), 17.0 (C-8), 6.5 (C-7).

(-)-(Z)-2-Hydroxy-6-(hydroxyimino)-2,5-dimethylcyclohex-4-ene1,3-dione 28 . The assay was repeated at larger scale $(16 \mathrm{ml})$ with $2.5 \mathrm{mM}$ of substrate. After complete conversion of the substrate, the reaction mixture was acidified, clarified by centrifugation and purified directly by mass-directed LC/MS.

Colourless oil, $\alpha[\mathrm{D}]-48.5,(c$ 0.35, $\mathrm{MeOH}) ; \mathrm{UV}\left(\mathrm{CH}_{3} \mathrm{CN} / \mathrm{H}_{2} \mathrm{O}\right)$ $\lambda_{\max } 274 \mathrm{~nm} ;{ }^{1} \mathrm{H}-\mathrm{NMR}\left(500 \mathrm{MHz}, \mathrm{CD}_{3} \mathrm{CN}\right) \delta_{\mathrm{H}}=8.06(\mathrm{~s}, \mathrm{~N}-\mathrm{OH})$, $6.28\left(\mathrm{~d},{ }^{4} J=1.2,1 \mathrm{H}, 4-\mathrm{H}\right), 2.16\left(\mathrm{~d},{ }^{4} J=1.2,3 \mathrm{H}, 8-\mathrm{H}\right), 1.47(\mathrm{~s}$, $3 \mathrm{H}, 7-\mathrm{H}) ;{ }^{13} \mathrm{C}-\mathrm{NMR}\left(125 \mathrm{MHz}, \mathrm{CD}_{3} \mathrm{CN}\right) \delta_{\mathrm{c}}=196.5(\mathrm{C}-3), 192.8(\mathrm{C}-$ 1), 152.8 (C-5), 149.4 (C-6), 127.9 (C-4), 86.0 (C-2), 25.8 (C-7), 18.2 (C-8); HRMS for $\mathrm{C}_{8} \mathrm{H}_{9} \mathrm{NaNO}_{4}$ calcd: 206.04249; found: 206.04237 $[\mathrm{M}] \mathrm{Na}^{+}$.

\section{Preparative LC-MS}

The purification of compounds was achieved using a Waters mass-directed autopurification system comprising of a Waters 2767 autosampler, Waters 2545 pump system, a Phenomenex LUNA column $\left(5 \mu, \mathrm{C}_{18}, 100 \AA\right.$, $\left.10 \times 250 \mathrm{~mm}\right)$ equipped with a Phenomenex Security Guard precolumn (Luna $\mathrm{C}_{5} \quad 300 \AA$ A)

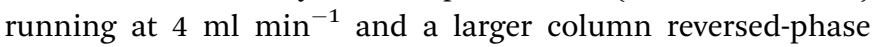
HPLC (Phenomenex, Kinetex, $5 \mu \mathrm{m} \mathrm{C}_{18} 100 \AA$ A, AXIA Packed LC Column $250 \times 21.2 \mathrm{~mm}$ ) with a flow rate of $16 \mathrm{ml} \mathrm{min}^{-1}$. Solvents were HPLC grade including $\mathrm{H}_{2} \mathrm{O}, \mathrm{CH}_{3} \mathrm{CN}$ and $\mathrm{MeOH}$ with the addition of $0.05 \%$ formic acid in all the solvent. The post-column flow was split $(100: 1)$ and the minority flow was made up with $\mathrm{MeOH}+0.045 \%$ formic acid to $1 \mathrm{ml} \mathrm{min}^{-1}$ for simultaneous analysis by diode array (Waters 2998), evaporative light scattering (Waters 2424) and ESI mass spectrometry in positive and negative modes (Waters Quatro Micro). Detected peaks were collected into glass test tubes. Combined tubes were evaporated under a flow of dry $\mathrm{N}_{2}$ gas, weighed, and residues dissolved directly in deuterated solvents for NMR analysis. Solvent gradients for LC/MS analytical and purification were variable but generally runs of 15, 30 and 60 min were designed to start with $95 \%$ Water (A) for 2 min to remove any salts present in a sample. Next, the polarity of the solvent system was increased accordingly for good separation. Before the run ended, 2 min wash of 95\% organic solvent $\mathrm{CH}_{3} \mathrm{CN}$ (B) or $\mathrm{MeOH}$ (C) was applied to ensure the elution of all compounds. Finally, the HPLC column was prepared for the next run by adding 2 min $95 \%$ Water at the end of the programme.

\section{Recombinant protein overproduction and purification}

Recombinant hexa-histidine tagged TropB produced by overexpression in BL21-CodonPlus (DE3)-RP (Stratagene) using the plasmid pET-28a-TropB originally described by Davison and coworkers. ${ }^{4}$ Overproduction and purification of the protein was according to established protocols with the exception of the inclusion of $10 \%$ glycerol in all purification buffers and the use of a HiLoad 16/60 Superdex 200 column (GE Healthcare) for size exclusion chromatography (see ESI Fig. S1†).

\section{Protein Identification from SDS-PAGE gels by MALDI}

The appropriate coomassie stained band was excised from the SDS-PAGE gel, cut into $1 \mathrm{~mm}$ cubes and destained overnight with $50 \%$ ethanol. The sample was washed with $100 \mathrm{mM}$ ammonium bicarbonate and dehydrated several times with acetonitrile. Reduction and alkylation was achieved by incubation with $50 \mathrm{mM}$ DTT at $56^{\circ} \mathrm{C}$ for 1 hour followed by cooling to room temperature and incubation with $50 \mathrm{mM}$ iodoacetamide for 45 minutes in the dark. Gel pieces were washed with $100 \mathrm{mM}$ ammonium bicarbonate and dehydrated with acetonitrile several times before the addition of $12.5 \mathrm{ng} \mathrm{\mu l}^{-1}$ trypsin solution (Promega) in $50 \mathrm{mM}$ ammonium bicarbonate and incubated at $37{ }^{\circ} \mathrm{C}$ overnight. Peptide fragments were extracted from the gel by several rounds of sonication in acetonitrile using a water bath sonicator. The solution was dried overnight under vacuum and resuspended in $10 \mu \mathrm{l}$ of $50 \%$ acetonitrile.

Samples were spotted onto a stainless steel plate with an equal volume of matrix (a saturated solution of $\alpha$-cyano-4hydroxycinnaminic acid in 50\% acetonitrile) and left to dry. A mass spectrum was recorded with a MALDI-TOF spectrometer (4700 Proteomics Analyzer, Applied Biosystems) in linear mode.

The peptides masses resulting from this analysis were submitted to the Mascot Peptide Mass Fingerprint search engine (http://www.matrixscience.com; Matrix Science, London, UK) to search for matching proteins in NCBInr database (see ESI Fig. S2†).

\section{LC-MS activity assay}

Enzyme activity was measured in a $1 \mathrm{ml}$ final volume with 50 $\mathrm{mM}$ phosphate buffer $\mathrm{pH} 8,2.5 \mathrm{mM}$ for each individual compound and $20 \mu \mathrm{g} \mathrm{ml}^{-1}(0.38 \mu \mathrm{M})$ TropB. The reaction was initiated by adding $2.5 \mathrm{mg}$ of NADPH (final concentration 3 $\mathrm{mM}$ ) and was incubated for 60 minutes under aerobic conditions at $30{ }^{\circ} \mathrm{C}$. The reaction product was extracted by ethylacetate and detected by LC-MS. A Phenomenex LUNA column (5 $\mu, \mathrm{C}_{18}, 100 \AA$, $4.6 \times 250 \mathrm{~mm}$ ) was used with a gradient elution of acetonitrile: $0 \mathrm{~min}, 10 \% \mathrm{~B} ; 15 \mathrm{~min}, 90 \% \mathrm{~B} ; 16 \mathrm{~min}, 95 \% \mathrm{~B} ; 17$ $\min , 95 \% \mathrm{~B} ; 18 \mathrm{~min}, 10 \% \mathrm{~B} ; 20 \mathrm{~min}, 10 \% \mathrm{~B}$. Mass spectrometry was performed with a Waters ZQ micromass spectrometer. 
Control reactions were carried out under identical conditions but using boiled enzyme.

\section{Determination of optimum temperature and $\mathrm{pH}$}

Enzyme activity was measured across a range of 5 to $40{ }^{\circ} \mathrm{C}$ in 50 $\mathrm{mM}$ Tris-HCl buffer ( $\mathrm{pH}$ 8.0) at a fixed concentration of enzyme. NADPH $\left(\begin{array}{ll}100 & \mu \mathrm{M}\end{array}\right)$ and the natural substrate 3-methylorcinaldehyde $(200 \mu \mathrm{M})$ were included in each reaction mix. Reactions were performed in a $100 \mu \mathrm{l}$ volume in transparent 96 well microplates (Costar). Activity was measured by monitoring the initial rate of increase of product formation at $400 \mathrm{~nm}$ in a Molecular Devices SpectraMAX 190 microplate reader. Known concentrations of product (dienone) were used to generate a standard curve from which the increase in absorbance could be converted into an increase of product concentration. The reaction rate was recorded from the linear portion of a graph showing product concentration against time. To ensure the reactions occurred at the required temperature, solutions were pre-incubated at that temperature for 30 minutes in either a heat block or cooling shaker. All reactions were repeated in triplicate.

To measure the effect of $\mathrm{pH}$ on activity, the above protocol was used except temperature was fixed at $30{ }^{\circ} \mathrm{C}$ and different reaction buffers were used to create a $\mathrm{pH}$ range of 5-12. The following buffers were used: $50 \mathrm{mM}$ sodium acetate $\mathrm{pH}$ 5.0, sodium phosphate $\mathrm{pH} 6.0$, Tris- $\mathrm{HCl} \mathrm{pH} \mathrm{7.0,} \mathrm{Tris-HCl-8.0,} \mathrm{Tris-}$ HCl-9.0, CHES pH 10.0 and CHES pH 12.0.

\section{Determination of kinetic parameters}

Reactions were monitored by following either the increase of product formation at $400 \mathrm{~nm}$ or the depletion of NADPH at 340 $\mathrm{nm}$ using a Carey 50 spectrophotometer (Agilent). In cases where the product absorbance was monitored the reactions were allowed to reach completion and the final absorbance value was used to calculate the extinction coefficient using the Beer-Lambert law. The extinction coefficient was used to convert absorbance units into product concentration for plotting graphs of concentration against time. When NADPH depletion was monitored the universally recognised extinction coefficient of $6.2 \times 10^{3} \mathrm{M}^{-1} \mathrm{~cm}^{-1}$ was used for the same purposes.

Reactions were performed in $100 \mu \mathrm{l}$ final volume containing $0.4 \mathrm{mg} \mathrm{ml}{ }^{-1}$ TropB, $100 \mu \mathrm{M}$ NADPH, buffer $(50 \mathrm{mM}$ Tris-HCl $\mathrm{pH} 8.0,150 \mathrm{mM} \mathrm{NaCl}, 10 \%$ glycerol) and varying concentrations of substrate (see ESI $\dagger$ ). All reactions were carried out in triplicate.

Kinetic parameters were estimated by plotting initial reaction rate against substrate concentration and fitting the data to the Michaelis-Menten equation using GraphPad Prism version 5.00 for Windows, GraphPad Software, San Diego California USA, http://www.graphpad.com.

\section{TropB modeling and docking studies}

A homology model of TropB was generated using the SWISSMODEL protein structure homology-modelling server in the fully automated mode. ${ }^{20-23}$ The PDB entry $4 b j y$ was used as the template structure. ${ }^{17}$ This enzyme shares $25 \%$ sequence identity to TropB and is a known FAD dependent hydroxylase. The resulting model was structurally aligned with the template $4 b j y$ in Pymol (The PyMOL Molecular Graphics System, Version 1.3 Schrödinger, LLC.) and the 3D co-ordinates of the FAD ligand were merged from $4 b j y$ into the homology model file. The resulting protein-ligand complex was subjected to energy minimisation using the YASARA energy minimization server. ${ }^{24}$ The substrate, 3-methylorcinaldehyde $\mathbf{1}$ was manually positioned within the TropB active site using Pymol and the resulting protein-ligand complex again subjected to energy minimization using the YASARA energy minimization server. To evaluate TropB substrate tolerability 3-methylorcinaldehyde $\mathbf{1}$ was substituted for a representative selection of compounds listed in Table 1 and their ability to be accommodated with the TropB active site assessed using the same methodology. The electrostatic surface was generated using the PDB2PQR server ${ }^{25}$ and the APBS Pymol Plugin. ${ }^{26}$

\section{Acknowledgements}

PRR is the recipient of a Royal Society University Research Fellowship. AA thanks the Ministry of Higher Education (mission sector-Egypt) for a Channel studentship; AAF thanks Al Baha University, Saudi Arabia for funding. We thank EPSRC for LCMS equipment (EP/F066104/1). AS was funded by BBSRC (BB/ I003355/1).

\section{References}

1 R. Ullrich and M. Hofrichter, Cell. Mol. Life Sci., 2007, 64, 271-293.

2 M. M. E. Huijbers, S. Montersino, A. H. Westphal, D. Tischler and W. J. H. van Berkel, Arch. Biochem. Biophys., 2014, 544, 217.

3 A. Meyer, M. Held, A. Schmid, H.-P. E. Kohler and B. Witholt, Biotechnol. Bioeng., 2003, 81, 518-524.

4 J. Davison, A. Al Fahad, M. Cai, Z. S. Song, S. Y. Yehia, C. M. Lazarus, A. M. Bailey, T. J. Simpson and R. J. Cox, Proc. Natl. Acad. Sci. U. S. A., 2012, 109, 7642-7647.

5 J. Zhu, N. P. Grigoriadis, J. P. Lee and J. A. Porco, J. Am. Chem. Soc., 2005, 127, 9342-9343.

6 J. Zhu and J. A. Porco, Org. Lett., 2006, 8, 5169-5171.

7 A. Al Fahad, A. Abood, K. M. Fisch, A. Osipow, J. Davison, M. Avramović, C. P. Butts, J. Piel, T. J. Simpson and R. J. Cox, Chem. Sci., 2014, 5, 523-527.

8 S. Paul, P. Nanda, R. Gupta and A. Loupy, Synthesis, 2003, 2877-2881.

9 F. Arnall, J. Chem. Soc., 1924, 125, 811-816.

10 T. McCullough and K. Kubena, J. Chem. Educ., 1990, 67, 801. 11 R. A. Raphael and P. Ravenscroft, J. Chem. Soc., Perkin Trans. 1, 1988, 1823-1828.

12 K. Iokhannes, L. I. Melder, L. V. Tiikma and E. A. Sidoruk, Russ. J. Appl. Chem., 1995, 68, 1159-1162.

13 B. Yuan, N. Yokochi, Y. Yoshikane, K. Ohnishi and T. Yagi, J. Biosci. Bioeng., 2006, 102, 504-510. 
14 K. M. McCulloch, T. Mukherjee, T. P. Begley and S. E. Ealick, Biochemistry, 2009, 48, 4139-4149.

15 N. Abe, O. Sugimoto, T. Arakawa, K. Tanji and A. Hirota, Biosci., Biotechnol., Biochem., 2001, 65, 2271-2279.

16 S. Montersino, R. Orru, A. Barendregt, A. H. Westphal, E. Van Duijn, A. Mattevi and W. J. H. Van Berkel, J. Biol. Chem., 2013, 288, 26235-26245.

17 F. Corpet, Nucleic Acids Res., 1988, 16, 10881-10890.

18 X. Robert and P. Gouet, Nucleic Acids Res., 2014, 42, W320W324.

19 D. J. Cram, J. Am. Chem. Soc., 1948, 70, 4244-4247.

20 M. Biasini, S. Bienert, A. Waterhouse, K. Arnold, G. Studer, T. Schmidt, F. Kiefer, T. Gallo Cassarino, M. Bertoni, L. Bordoli and T. Schwede, Nucleic Acids Res., 2014, 42, W252-W258.
21 K. Arnold, L. Bordoli, J. Kopp and T. Schwede, Bioinformatics, 2006, 22, 195-201.

22 F. Kiefer, K. Arnold, M. Künzli, L. Bordoli and T. Schwede, Nucleic Acids Res., 2009, 37, D387-D392.

23 N. Guex, M. C. Peitsch and T. Schwede, Electrophoresis, 2009, 30, S162-S173.

24 E. Krieger, K. Joo, J. Lee, J. Lee, S. Raman, J. Thompson, M. Tyka, D. Baker and K. Karplus, Proteins, 2009, 77(suppl. 9), 114-122.

25 T. J. Dolinsky, J. E. Nielsen, J. A. McCammon and N. A. Baker, Nucleic Acids Res., 2004, 32, W665-W667.

26 N. A. Baker, D. Sept, S. Joseph, M. J. Holst and J. A. McCammon, Proc. Natl. Acad. Sci. U. S. A., 2001, 98, 10037-10041. 